\title{
Przegląd i analiza wymagań prawnych w zakresie możliwości gospodarowania odpadami pochodzącymi z działalności górnictwa nafty i gazu
}

\author{
Review and analysis of legal requirements regarding the possibilities of management \\ of waste from the oil and gas industry
}

\author{
Ewa Kukulska-Zając, Anna Król \\ Instytut Nafty i Gazu - Państwowy Instytut Badawczy
}

\begin{abstract}
STRESZCZENIE: Poszukiwanie i eksploatacja złóż węglowodorów wiążą się z generowaniem odpadów wiertniczych, które zaliczane są do odpadów wydobywczych. Gospodarowanie odpadami wydobywczymi podlega wymaganiom zawartym w regulacjach prawnych zarówno na poziomie UE, jak i na poziomie krajowym. Zgodnie z zapisami zawartymi w obowiązujących aktach prawnych w tym zakresie w pierwszej kolejności rekomendowane jest zapobieganie powstawaniu odpadów wydobywczych oraz ograniczanie ilości wytwarzanych odpadów wydobywczych i ich wpływu na środowisko. Kolejnym krokiem w zagospodarowywaniu odpadów wydobywczych jest ich odzysk, a ostatnim unieszkodliwianie poprzez składowanie na odpowiedniego typu składowiskach. W niniejszym artykule omówiono obowiązujące regulacje prawne, krajowe i wspólnotowe, dotyczące możliwości zagospodarowania odpadów powstających w wyniku działalności górnictwa nafty i gazu. Ilość obowiązujących aktów prawnych w przedmiotowym obszarze jest stosunkowo duża, a wśród najważniejszych regulacji wymienić należy: Ustawę z dnia 10 lipca 2008 r. o odpadach wydobywczych (Ustawa z dnia 10 lipca 2008 r.), Ustawę z dnia 14 grudnia 2012 r. o odpadach (Ustawa z dnia 14 grudnia 2012 r.) oraz Ustawę z dnia 9 czerwca 2011 r. - Prawo geologiczne i górnicze (Ustawa z dnia 9 czerwca 2011 r.). Przeprowadzony przegląd pokazał wyraźnie, że należy dążyć do ograniczania ilości wytwarzanych odpadów wydobywczych i ich ponownego wykorzystania. W świetle obowiązujących regulacji prawnych do odpadów wiertnicznych można zastosować kilka z rekomendowanych w załączniku do Ustawy (Ustawa z dnia 14 grudnia 2012 r.) sposobów unieszkodliwiania odpadów, tj. procesy D1 (składowanie w gruncie lub na powierzchni ziemi), D2 (przetwarzanie w glebie i ziemi), D3 (głębokie zatłaczanie), D5 (składowanie na składowiskach w sposób celowo zaprojektowany), D7 (odprowadzanie do mórz i oceanów) oraz D9 (obróbka fizyczno-chemiczna). Składowanie takich odpadów na składowiskach jest ostatecznością. Odpady wydobywcze, w tym wiertnicze, można zgodnie z obowiązującymi regulacjami prawnymi składować w podziemnym składowisku odpadów lub w obiekcie unieszkodliwiania odpadów wydobywczych. Jednak mimo stosunkowo dużej ilości aktów prawnych dotyczących możliwego zagospodarowania odpadów wydobywczych na poziomie krajowym, brak jest nadal uregulowań wyczerpujących całą tematykę gospodarowania tego typu odpadami. Ponadto polskie prawo jest często w przedmiotowym zakresie także niespójne.
\end{abstract}

Słowa kluczowe: odpady wiertnicze, gospodarka odpadami wydobywczymi, górnictwo nafty i gazu.

ABSTRACT: The exploration and exploitation of hydrocarbon deposits is associated with the generation of drilling waste, which is classified as extractive waste. Extractive waste management is subject to the requirements contained in legal regulations at both EU and national level. In accordance with the provisions of applicable legal acts, it is recommended to prevent the production of extractive waste, to limit its generated amount and the impact on the environment. The next step in the management of extractive waste is its recovery, and the last is disposal in appropriate landfills. This article discusses applicable legal, national and EU regulations regarding the possibilities of waste management arising from the activity of oil and gas mining. The number of applicable legal acts in the area is relatively large, and the most important regulations include the Extractive Waste Act of July 10, 2008 (Ustawa z dnia 10 lipca 2008 r.), Waste Act of December 14, 2012 (Ustawa z dnia 14 grudnia 2012 r.) and the Act of June 9, 2011 - Geological and Mining Law (Ustawa z dnia 9 czerwca 2011 r.). The review has clearly shown that efforts should be made to reduce the amount of the extractive waste generated and to reuse it. In the light of applicable legal regulations, several of the waste disposal methods recommended in the Annex to the Act (Ustawa $\mathrm{z}$ dnia 14 grudnia 2012 r.) can be applied to drilling waste, i.e. D1 processes (storage in the ground or on the soil surface), D2 (processing in the soil and on the ground), D3 (deep injection), D5 (storage in landfills in a deliberately designed way), D7 (discharge to seas and oceans) and D9

Autor do korespondencji: E. Kukulska-Zając, e-mail: ewa.kukulska@inig.pl

Artykuł nadesłano do Redakcji: 01.05.2020 r. Zatwierdzono do druku: 04.08.2020 r. 
(physico-chemical treatment). Storage of such waste in landfills is the last resort. Extractive waste, including drilling waste, may be stored in an underground waste disposal facility or in an extractive waste disposal facility in accordance with applicable legal regulations. However, despite the relatively large number of legal acts regarding the possible management of extractive waste at the national level, there are still no regulations exhausting the entire subject of managing this type of waste. In addition, Polish law is often inconsistent in this respect.

Key words: drilling waste, extractive waste management, oil and gas industry.

\section{Wstęp}

Gospodarka odpadami w Polsce, w tym odpadami pochodzącymi z działalności górnictwa nafty i gazu, oparta jest zarówno na unijnych, jak i krajowych aktach prawnych. W świetle obowiązujących w zakresie gospodarowania odpadami ustaw i rozporządzeń istotą nowoczesnego postępowania z odpadami jest zasada 3R, tj. reduce, reuse, recycle (rys. 1). Oznacza to kolejno: ograniczanie ilości powstających odpadów, ponowne wykorzystanie tych, których nie udało się ograniczyć oraz przetwarzanie surowców, których nie można użyć ponownie. Składowanie na składowiskach jest traktowane jako ostatnia z możliwości zagospodarowania odpadów. Aby osiągnąć wymienione cele i tym samym zapewnić wyższy poziom ochrony środowiska naturalnego i zdrowia ludzkiego, podejmowane są działania polegające między innymi: na zwiększaniu nacisku na pełne egzekwowanie obowiązującego prawa, na upraszczaniu i uaktualnianiu obowiązującego prawodawstwa oraz na podnoszeniu wiedzy i upowszechnianiu informacji w tym zakresie.

Odpady powstające w trakcie poszukiwania i eksploatacji złóż węglowodorów stanowią głównie zwierciny skalne oraz pozostałości stosowanej w trakcie wiercenia płuczki wiertniczej. Zwierciny to skruszone skały, piasek, muł i glina, wynoszone na powierzchnię podczas wiercenia otworu. Płuczki wiertnicze są złożonymi mieszankami koloidalnymi. Dwoma

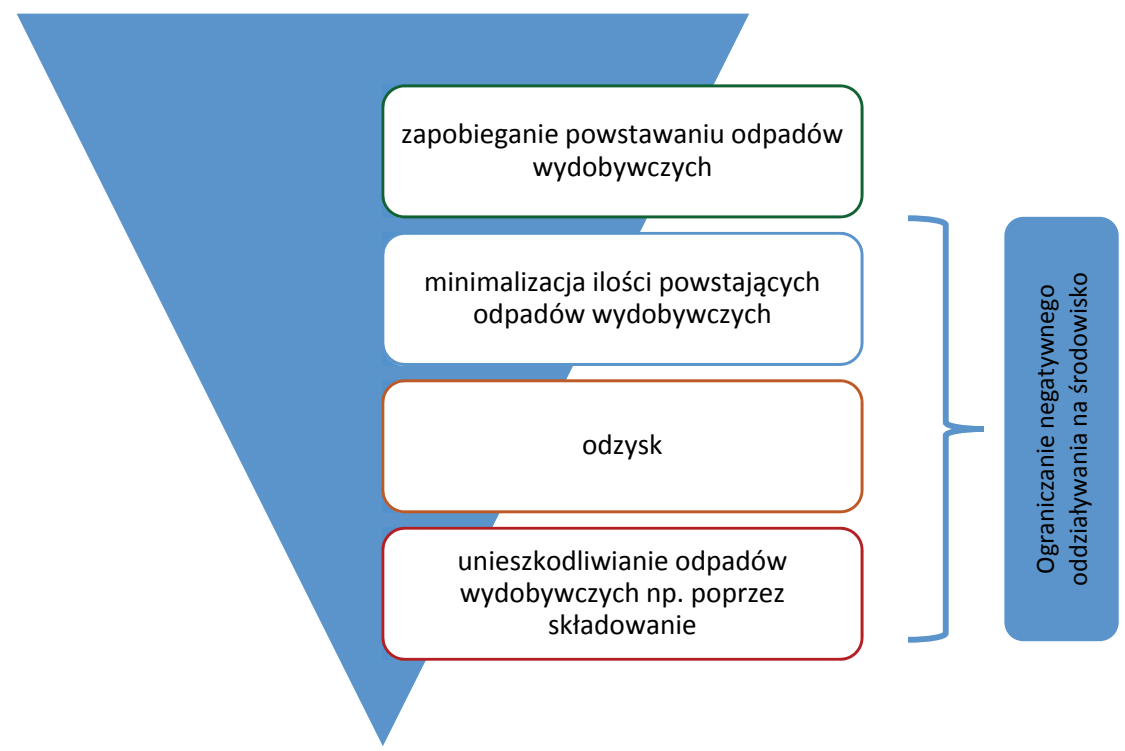

Rys. 1. Zasady postępowania z odpadami wydobywczymi

Fig. 1. Rules for dealing with extractive waste głównymi kategoriami płynów wiertniczych są płuczki na bazie wody (które mogą być rozproszone lub nierozproszone) i niewodne (np. na bazie syntetycznej). W przypadku prowadzenia prac na niekonwencjonalnych złożach węglowodorów do rodzaju powstających odpadów należy jeszcze dodać płyn zwrotny.

W Polsce aktualnie podczas wierceń generowane są głównie dwa pierwsze typy odpadów, tj. zwierciny oraz zużyte płuczki wiertnicze. Średnia ilość odpadów - zużytej płuczki i zwiercin - podczas jednego wiercenia wynosi od około 2500 do $6000 \mathrm{Mg}$ (Kujawska, 2020). Biorąc pod uwagę liczbę prowadzonych prac poszukiwawczych i eksploatacyjnych, skutkuje to wytwarzaniem corocznie stosunkowo dużych ilości odpadów wiertniczych. W związku z tym istotne staje się właściwe postępowanie $\mathrm{z}$ tego typu odpadami i dążenie do poszukiwania nowych metod zagospodarowania odpadów wiertniczych. W niniejszym artykule omówiono obowiązujące regulacje prawne, krajowe i wspólnotowe, dotyczące zagospodarowania odpadów powstających w wyniku działalności górnictwa nafty i gazu.

\section{Gospodarka odpadami wydobywczymi w świetle wymagań UE}

Na poziomie unijnym gospodarka odpadami wydobywczymi, a więc także odpadami powstającymi w wyniku działalności górnictwa naftowego i gazownictwa, jest regulowana Dyrektywą 2006/21/WE Parlamentu Europejskiego i Rady z dnia 15 marca 2006 r. w sprawie gospodarowania odpadami pochodzącymi z przemysłu wydobywczego oraz zmieniająca dyrektywę 2004/35/WE (Dyrektywa 2006/21/WE). Dyrektywa określa środki, procedury i wskazówki mające na celu zapobieganie lub zmniejszanie, w najszerszym możliwym zakresie, wszelkich niekorzystnych skutków dla środowiska, w szczególności wody, powietrza, gleby, fauny i flory oraz krajobrazu, jak również wszelkich wynikających z tego zagrożeń dla zdrowia ludzkiego, spowodowanych gospodarowaniem odpadami pochodzącymi z przemysłu wydobywczego. Dyrektywa obejmuje gospodarowanie odpadami pochodzącymi z poszukiwania, wydobywania, przeróbki i magazynowania surowców 
mineralnych oraz z działalności odkrywkowej. Odpady, które podlegają Dyrektywie (Dyrektywa 2006/21/WE), nie podlegają Dyrektywie Rady 1999/31/WE z dnia 26 kwietnia 1999 r. w sprawie składowania odpadów (Dyrektywa 1999/31/WE).

Zgodnie z zapisami Art. 5 Dyrektywy (Dyrektywa 2006/21/WE) operator (osoba fizyczna lub prawna odpowiedzialna za gospodarowanie odpadami wydobywczymi, zgodnie z prawem krajowym państwa członkowskiego, w którym gospodarowanie odpadami ma miejsce, $w$ tym za tymczasowe magazynowanie odpadów wydobywczych, jak również za fazę eksploatacyjną i poeksploatacyjną) ma obowiązek sporządzenia planu gospodarowania odpadami w celu zminimalizowania, przeróbki, odzysku oraz unieszkodliwiania odpadów wydobywczych, uwzględniając zasadę zrównoważonego rozwoju. Celami opracowanego planu gospodarowania odpadami są:

- zapobieganie i zmniejszanie wytwarzania odpadów oraz ich szkodliwości (poprzez między innymi umieszczanie odpadów wydobywczych z powrotem w wyrobiskach po wydobyciu minerału, w takim zakresie w jakim jest to wykonalne pod względem technicznym i ekonomicznym oraz uzasadnione pod względem środowiskowym, czy stosowanie mniej niebezpiecznych substancji do przeróbki surowców mineralnych);

- zachęcanie do odzysku odpadów wydobywczych za pomocą recyklingu, ponownego użycia lub regeneracji takich odpadów, tam gdzie jest to uzasadnione pod względem środowiskowym;

- zapewnianie krótko- i długoterminowego bezpiecznego unieszkodliwiania odpadów wydobywczych.

Plan gospodarowania odpadami powinien zawierać informacje dotyczące między innymi:

- propozycji klasyfikacji obiektu unieszkodliwiania odpadów zgodnie z kryteriami określonymi w załączniku III do Dyrektywy (Dyrektywa 2006/21/WE) (tam gdzie to stosowne);

- charakterystyki odpadów, zgodnie z załącznikiem II do Dyrektywy (Dyrektywa 2006/21/WE) oraz oświadczenia o przewidywanych łącznych ilościach odpadów wydobywczych, które będą wytwarzane w fazie operacyjnej;

- opisu procesów, w trakcie których wytwarzane są takie odpady oraz wszelkich dalszych procesów przeróbki, którym są one poddane;

- opisu ewentualnych niekorzystnych skutków dla środowiska i zdrowia ludzkiego poprzez składowanie takich odpadów;

- opisu środków zapobiegawczych, które należy przedsięwziąć w celu zmniejszenia wpływu na środowisko w czasie eksploatacji obiektu unieszkodliwiania odpadów i po jego zamknięciu;

- przeglądu stanu gruntów, na które wpływ będzie wywierał obiekt unieszkodliwiania odpadów.
Celem wykonania charakterystyki odpadów wydobywczych jest uzyskanie odpowiednich informacji na ich temat. Pozwoli to na ocenę i monitorowanie właściwości odpadów oraz ich cech charakterystycznych, a tym samym zagwarantowanie, że odpady te zostaną objęte długoterminowym programem zarządzania w warunkach bezpiecznych dla środowiska. Ponadto charakterystyka odpadów pochodzących z przemysłu wydobywczego powinna pozwolić na określenie możliwości gospodarowania takimi odpadami oraz powiązanych z nimi środków ochrony środowiska i zdrowia człowieka.

Informacje zawarte w planie powinny być wystarczające, aby umożliwić właściwemu organowi ocenę zdolności operatora do osiąnnięcia celów planu gospodarowania odpadami oraz jego obowiązków wynikających z niniejszej Dyrektywy. Opracowany plan podlega przeglądowi co pięć lat lub aktualizacji, w przypadku istotnych zmian w działaniu obiektu unieszkodliwiania odpadów lub w odniesieniu do odpadów, które są składowane i jest zatwierdzany oraz monitorowany przez właściwy organ.

Zgodnie z zapisami Dyrektywy (Dyrektywa 2006/21/WE) odpady wydobywcze mogą być składowane:

- w obiekcie unieszkodliwiania odpadów, czyli na terenie przeznaczonym do gromadzenia lub składowania odpadów wydobywczych (zarówno w formie stałej, ciekłej, w roztworze lub zawiesinie) przez odpowiednie okresy czasu;

- w wyrobiskach poeksploatacyjnych (powstałych zarówno wskutek eksploatacji odkrywkowej, jak i podziemnej) i wykorzystane w celach rekultywacyjnych i technologicznych (Art. 10).

Dyrektywa (Dyrektywa 2006/21/WE) dopuszcza również możliwość zrzutu odpadów wydobywczych, w formie stałej, szlamu lub płynnej, do wszelkich odbiorników wodnych innych niż skonstruowanych w celach zrzutu odpadów wydobywczych, pod warunkiem spełnienia przez operatora odpowiednich wymagań dyrektyw 76/464/EWG, 80/68/EWG i 2000/60/WE. Uzupełnieniem Dyrektywy (Dyrektywa 2006/21/WE), doprecyzowującym jej zapisy są opublikowane decyzje, które dotyczą między innymi kryteriów klasyfikacji obiektów unieszkodliwiania odpadów oraz wymogów technicznych w odniesieniu do charakterystyki odpadów.

Omawiając wymagania unijne dotyczące gospodarowania odpadami wydobywczymi należy odnieść się również do dokumentów BREF (BAT REFerence note). Dokumenty te co prawda nie stanowią regulacji prawnych, ale są wymogiem UE i obejmują opisy technik różnych gałęzi przemysłowych ze wskazaniem technik najlepszych ekologicznie, aby służyć państwom członkowskim jako odniesienie przy wydawaniu pozwoleń środowiskowych. W grudniu 2018 roku został wydany dokument BREF dla gospodarowania odpadami z przemysłu wydobywczego pn.: Best Available 
Techniques (BAT) Reference Document for the Management of Waste from Extractive Industries (Garbarino et al., 2018), w skrócie MWEI BREF.

MWEI BREF przedstawia zaktualizowane dane i informacje dotyczące gospodarowania odpadami pochodzącymi z szeroko rozumianego przemysłu wydobywczego, w tym informacje na temat BAT dla sektora wydobycia ropy i gazu. W poszczególnych częściach tego obszernego dokumentu zawarto dane dotyczące procesów i metod stosowanych podczas gospodarowania różnego typu odpadami wydobywczymi, dane dotyczące technik istotnych do rozważenia przy określaniu najlepszych dostępnych technik (BAT) oraz informacje odnoszące się do BAT w przedmiotowym zakresie. W dokumencie tym podano możliwe metody szeroko rozumianego zagospodarowania odpadów z sektora wydobycia ropy i gazu. Należy dodać, że nie wszystkie wymienione w MWEI BREF metody zostały ostatecznie uwzględnione jako najlepsze dostępne techniki (BAT) dla sektora wydobycia ropy i gazu.

W MWEI BREF zwrócono również uwagę, że w przypadku sektora wydobycia ropy i gazu ma miejsce zewnętrzne zarządzanie odpadami wydobywczymi. W sektorze tym operatorzy odpowiedzialni za gospodarowanie takimi odpadami zwykle zbierają i wysyłają wytworzone odpady do instalacji ich przetwarzania. Instalacje te zwykle nie przetwarzają wyłącznie odpadów wydobywczych. Możliwe jest też składowanie części lub wszystkich powstałych odpadów wiertniczych (stałych i płynnych).

\section{Krajowe regulacje prawne dotyczące gospodarowania odpadami pochodzącymi z działalności górnictwa nafty i gazu}

Na poziomie krajowym gospodarka odpadami powstającymi w wyniku działalności górnictwa nafty i gazu jest regulowana przede wszystkim Ustawą z dnia 10 lipca $2008 \mathrm{r}$. o odpadach wydobywczych (Ustawa z dnia 10 lipca 2008 r.) i wydanymi na jej podstawie aktami wykonawczymi, opisanymi w literaturze przedmiotu (Krasińska i Król, 2012; Kukulska-Zając i Dobrzańska, 2012). Ustawa (Ustawa z dnia 10 lipca 2008 r.) transponuje do prawodawstwa krajowego zapisy Dyrektywy (Dyrektywa 2006/21/WE). Celem ww. Ustawy jest zapobieganie powstawaniu w przemyśle wydobywczym odpadów wydobywczych oraz ograniczanie ich niekorzystnego wpływu na środowisko i zdrowie ludzi. Ustawa określa między innymi zasady gospodarowania odpadami wydobywczymi, zasady prowadzenia obiektu unieszkodliwiania odpadów wydobywczych oraz procedury związane z uzyskiwaniem zezwoleń i pozwoleń związanych z gospodarką odpadami wydobywczymi.
W świetle Ustawy (Ustawa z dnia 10 lipca 2008 r.) odpady wydobywcze to odpady pochodzące z poszukiwania, rozpoznawania, wydobywania, przeróbki i magazynowania kopalin ze złóż. Zgodnie z tą definicją odpady wiertnicze powstające podczas działalności górnictwa nafty i gazu należą do tego typu odpadów. Natomiast obiekt unieszkodliwiania odpadów wydobywczych to obiekt przeznaczony do składowania odpadów wydobywczych w formie stałej, ciekłej, w roztworze lub zawiesinie (w tym hałdy i stawy osadowe) obejmujący tamy lub inne konstrukcje służące do powstrzymywania, zatrzymywania, ograniczania lub umacniania takiego obiektu. Należy dodać, że za obiekt unieszkodliwiania odpadów wydobywczych nie uznaje się wyrobiska górniczego wypełnianego odpadami wydobywczymi w celach rekultywacyjnych i technologicznych.

Zasady gospodarowania odpadami wydobywczymi zostały określone w Rozdziale 2 Ustawy (Ustawa z dnia 10 lipca 2008 r.). Artykuł 4 niniejszej Ustawy stanowi, że wytwórca odpadów wydobywczych jest obowiązany do stosowania takich sposobów poszukiwania, rozpoznawania, wydobywania, przeróbki i magazynowania, które zapobiegają powstawaniu tego typu odpadów lub pozwalają utrzymać ich ilość na możliwym najniższym poziomie. Stosowane sposoby powinny również zapewnić ograniczenie negatywnego oddziaływania na środowisko lub zagrożenia życia i zdrowia ludzi. Natomiast posiadacz odpadów wydobywczych jest obowiązany do:

- ograniczania negatywnego oddziaływania tych odpadów na środowisko, życie i zdrowie ludzi oraz zapobiegania lub zmniejszania wszelkich niekorzystnych skutków dla środowiska i zdrowia ludzi, powstałych w wyniku gospodarowania tymi odpadami, również po zamknięciu obiektu unieszkodliwiania odpadów wydobywczych;

- poddania odpadów odzyskowi (w pierwszej kolejności), a jeżeli z przyczyn technologicznych jest on niemożliwy lub z przyczyn ekonomicznych nieuzasadniony, do ich unieszkodliwienia zgodnie $\mathrm{z}$ wymaganiami ochrony środowiska lub programem gospodarowania odpadami wydobywczymi;

- przekazania odpadów (które z przyczyn technologicznych lub ekonomicznych nie mogą być poddane odzyskowi) do najbliżej położonych miejsc, w których mogą być poddane unieszkodliwieniu.

Wymienione zasady gospodarowania odpadami wydobywczymi powinny być wykonywane przy uwzględnieniu najlepszych dostępnych technik.

Zgodnie z Art. 7 odpady wydobywcze niebezpieczne po wytworzeniu powinny zostać niezwłocznie poddane odzyskowi lub unieszkodliwieniu, w tym składowaniu w obiekcie unieszkodliwiania odpadów wydobywczych. Ustawa (Ustawa z dnia 10 lipca 2008 r.) dopuszcza możliwość magazynowania 
odpadów wydobywczych niebezpiecznych, ale tylko tych, których wytworzenie było wcześniej niemożliwe do przewidzenia, jednak przez okres nie dłuższy niż 6 miesięcy. Odpady wydobywcze inne niż niebezpieczne i obojętne mogą być magazynowane przez okres nie dłuższy niż rok. Z kolei niezanieczyszczona gleba, odpady wydobywcze inne niż niebezpieczne wytworzone w czasie prac poszukiwawczych, odpady powstałe w wyniku wydobywania, przeróbki i magazynowania torfu oraz odpady wydobywcze obojętne mogą być magazynowane przez okres nie dłuższy niż 3 lata. Po upływie tych okresów, posiadacz odpadów wydobywczych jest obowiązany poddać je odzyskowi lub unieszkodliwieniu, w tym składowaniu w obiekcie unieszkodliwiania odpadów wydobywczych dla danego typu odpadów.

W Rozdziale 3 Ustawy (Ustawa z dnia 10 lipca 2008 r.) opisano natomiast program gospodarowania odpadami wydobywczymi, który posiadacz odpadów wydobywczych jest obowiązany przedłożyć właściwemu organowi przed rozpoczęciem działalności związanej z wytwarzaniem lub gospodarowaniem tego typu odpadami. Cele programu są kompatybilne z celami określonymi w Dyrektywie (Dyrektywa 2006/21/WE), jednak w przedmiotowej Ustawie zostały one doprecyzowane.

Program zagospodarowania odpadów wydobywczych dotyczyć musi zaplanowania całego „cyklu życia” odpadów już na etapie projektowym, od wydobycia aż po remediację obiektu unieszkodliwiania odpadów wydobywczych, przed rozpoczęciem samego wydobycia generującego odpady (rys. 2).

Program gospodarowania odpadami wydobywczymi (opracowany przez posiadacza takich odpadów) musi zostać zatwierdzony przez odpowiedni organ i powinien być przeglądany co 5 lat.

Ustawa (Ustawa z dnia 10 lipca 2008 r.) dopuszcza też możliwość wypełniania wyrobisk górniczych odpadami wydobywczymi. Taki sposób zagospodarowania tego typu odpadów powinien jednak odbywać się z uwzględnieniem zabezpieczenia stabilności odpadów, zapobiegania zanieczyszczeniu gleby, wód powierzchniowych i podziemnych oraz zapewnienia monitoringu wyrobisk górniczych wypełnianych takimi odpadami. Szczegółowe warunki składowania odpadów wydobywczych w wyrobiskach górniczych określa:
- Ustawa z dnia 9 czerwca 2011 r. - Prawo geologiczne i górnicze (Ustawa z dnia 9 czerwca 2011 r.) - w przypadku wypełniania wyrobisk górniczych odpadami wydobywczymi pochodzącymi z własnego zakładu górniczego lub odpadami wydobywczymi innymi niż z własnego zakładu górniczego, jeśli wypełnianie jest prowadzone w ruchu zakładu górniczego;

- Ustawa z dnia 14 grudnia 2012 r. o odpadach (Ustawa z dnia 14 grudnia 2012 r.) - do wypełniania wyrobisk górniczych odpadami wydobywczymi innymi niż z własnego zakładu górniczego.

W chwili obecnej Ustawa (Ustawa z dnia 10 lipca 2008 r.) posiada pięć aktów wykonawczych dotyczących między innymi szczegółowych kryteriów klasyfikacji obiektów unieszkodliwiania odpadów wydobywczych, kryteriów zaliczania odpadów wydobywczych do odpadów obojętnych czy charakterystyki odpadów wydobywczych. Sama Ustawa (Ustawa z dnia 10 lipca 2008 r.), jak i wydane na jej podstawie akty wykonawcze, nie wyczerpują całej tematyki związanej z zagospodarowaniem odpadów wydobywczych. W sprawach dotyczących postępowania z odpadami wydobywczymi w zakresie nieuregulowanym Ustawą (Ustawa z dnia 10 lipca 2008 r.) należy stosować zapisy Ustawy (Ustawa z dnia 14 grudnia 2012 r.), z wyłączeniem działu II rozdziału 7 (Magazynowanie odpadów) oraz działu VIII rozdziału 1 (Składowanie odpadów). W załączniku nr 1 do Ustawy (Ustawa z dnia 14 grudnia 2012 r.) podano niewyczerpujący wykaz procesów odzysku dla odpadów, a w załączniku nr 2 niewyczerpujący wykaz procesów unieszkodliwiania różnego typu odpadów. Pod pojęciem odzysk rozumie się jakikolwiek proces, którego głównym wynikiem jest to, aby odpady służyły użytecznemu zastosowaniu przez zastąpienie innych materiałów, które w przeciwnym przypadku zostałyby użyte do spełnienia danej funkcji, lub w wyniku którego odpady są przygotowywane do spełnienia takiej funkcji w danym zakładzie lub ogólnie w gospodarce. Natomiast unieszkodliwianie odpadów to proces niebędący odzyskiem, nawet jeżeli wtórnym skutkiem takiego procesu jest odzysk substancji lub energii. Unieszkodliwianiu poddaje się te odpady, z których uprzednio wysegregowano odpady

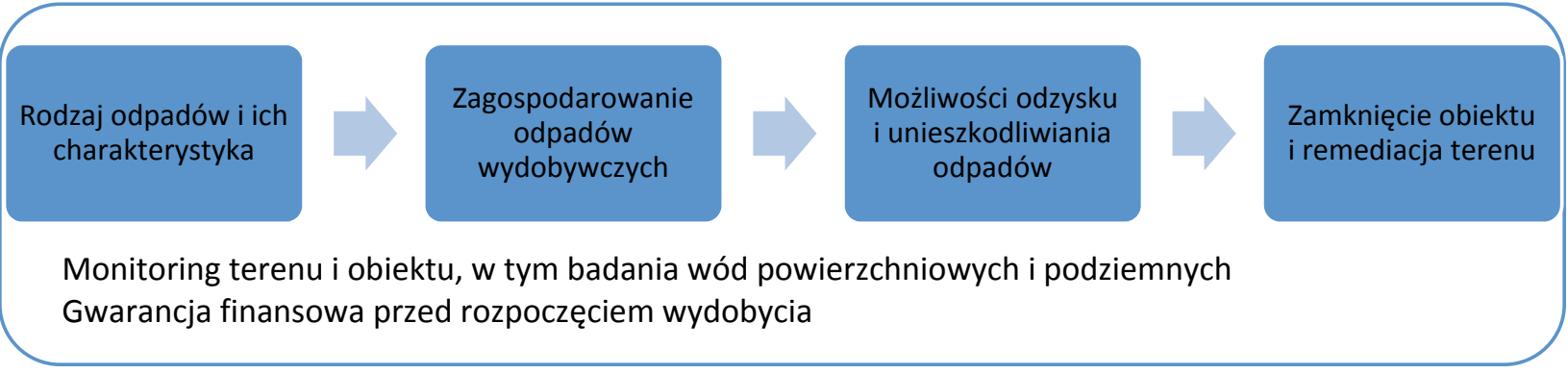

Rys. 2. Schemat programu gospodarowania odpadami wydobywczymi

Fig. 2. Scheme of the extractive waste management program 
nadające się do odzysku. Do odpadów wiertniczych nie można zastosować żadnego procesu odzysku z wymienionych w załączniku nr 1 do Ustawy (Ustawa z dnia 14 grudnia 2012 r.). Natomiast wśród wymienionych w załączniku nr 2 procesów unieszkodliwiania do odpadów wiertniczych można zastosować następujące procesy:

- D1 - składowanie w gruncie lub na powierzchni ziemi (np. składowiska itp.);

- D2 - przetwarzanie w glebie i ziemi (np. biodegradacja odpadów płynnych lub szlamów w glebie i ziemi itd.);

- D3 - głębokie zatłaczanie (np. zatłaczanie odpadów w postaci umożliwiającej pompowanie do odwiertów, wysadów solnych lub naturalnie powstających komór itd.);

- D5 - składowanie na składowiskach w sposób celowo zaprojektowany (np. umieszczanie w uszczelnionych oddzielnych komorach, przykrytych i izolowanych od siebie wzajemnie i od środowiska itd.);

- D7 - odprowadzanie do mórz i oceanów, w tym lokowanie na dnie mórz;

- D9 - obróbka fizyczno-chemiczna, niewymieniona w innej pozycji załącznika nr 2, w wyniku której powstają ostateczne związki lub mieszaniny unieszkodliwiane za pomocą któregokolwiek spośród procesów wymienionych w pozycjach D1-D12 (np. odparowanie, suszenie, kalcynacja itp.). Wśród możliwych sposobów unieszkodliwiania odpadów wydobywczych dopuszczone jest ich składowanie na składowiskach. Należy dodać, że odpady przed umieszczeniem na składowisku poddaje się zwykle procesowi przekształcenia fizycznego, chemicznego, termicznego lub biologicznego, włącznie z segregacją, w celu przede wszystkim ograniczenia zagrożenia dla życia i zdrowia ludzi lub dla środowiska. Takie działania służą również w celu ograniczeniu ilości lub objętości składowanych odpadów, a także ułatwieniu postępowania z nimi, w tym prowadzenia odzysku (Steliga et al., 2018a, 2018b). Procesów przekształcenia fizycznego, chemicznego, termicznego lub biologicznego, włącznie z segregacją nie stosuje się do odpadów obojętnych oraz odpadów, w stosunku do których procesy te nie doprowadzą do osiągnięcia wymienionych powyżej celów.

Omawiając regulacje prawne dotyczące możliwości zagospodarowania odpadów pochodzących z działalności górnictwa nafty i gazu, należy odnieść się także do zapisów Rozporządzenia Ministra Gospodarki z dnia 16 lipca 2015 r. w sprawie dopuszczania odpadów do składowania na składowiskach (Rozporządzenie Ministra Gospodarki z dnia 16 lipca 2015 r.). Rozporządzenie to określa między innymi kryteria dopuszczenia odpadów do składowania na składowisku odpadów danego typu. Zgodnie z tym Rozporządzeniem odpady mogą być składowane na trzech typach składowisk, tj.: na składowisku odpadów obojętnych, na składowisku odpadów innych niż niebezpieczne i obojętne oraz na składowisku odpadów niebezpiecznych. Zakres badań oraz kryteria dopuszczania odpadów do składowania na danego typu składowisku zostały określone w odpowiednich załącznikach do Rozporządzenia (Rozporządzenie Ministra Gospodarki z dnia 16 lipca 2015 r.).

Jak już wspomniano wcześniej, podczas analizy możliwości zagospodarowania odpadów wydobywczych należy uwzględnić również przepisy Ustawy (Ustawa z dnia 9 czerwca 2011 r.). Ustawa Prawo geologiczne i górnicze określa zasady i warunki podejmowania, wykonywania oraz zakończenia działalności w zakresie między innymi podziemnego składowania odpadów. Zgodnie z definicją zawartą w niniejszej Ustawie podziemnym składowiskiem odpadów jest część górotworu, w tym podziemne wyrobisko górnicze, wykorzystywana w celu unieszkodliwiania odpadów przez ich składowanie. Działalność w zakresie podziemnego składowania odpadów może być wykonywana po uzyskaniu koncesji, której udziela minister właściwy do spraw środowiska. We wniosku o udzielenie koncesji na podziemne składowanie odpadów określa się między innymi:

- sposób przeciwdziałania ujemnym wpływom na środowisko zamierzonej działalności;

- rodzaj, ilość oraz charakterystykę odpadów;

- aktualne i przewidywane warunki geologiczne, hydrogeologiczne i geologiczno-inżynierskie. W przypadku działalności polegającej na składowaniu odpadów promieniotwórczych warunki te odnoszą się do lokalizacji, budowy, eksploatacji, zamknięcia oraz do okresu po zamknięciu składowiska odpadów promieniotwórczych;

- technologię składowania.

Szczegóły dotyczące podziemnego magazynowania odpadów zawarte zostały w rozdziale 4 działu VI Ustawy (Ustawa z dnia 9 czerwca 2011 r.). W rozdziale tym zostały określone typy podziemnych składowisk odpadów oraz wyszczególniono odpady, których składowanie w górotworze i podziemnych wyrobiskach górniczych jest zabronione. Zgodnie z Art. 125 wyróżnia się cztery typy podziemnych składowisk odpadów, tj.: składowisko odpadów niebezpiecznych, składowisko odpadów obojętnych, składowisko odpadów promieniotwórczych oraz składowisko odpadów innych niż niebezpieczne, obojętne i promieniotwórcze. Natomiast zgodnie z Art. 126 zabronione jest podziemne składowanie odpadów, które:

- występują w postaci ciekłej, w tym odpadów zawierających wodę w ilości powyżej 95\% masy całkowitej, z wyłączeniem szlamów;

- $\quad$ posiadają właściwości wybuchowe, żrące, utleniające, wysoce łatwopalne lub łatwopalne;

- w warunkach podziemnego składowania mogą podlegać niepożądanym zmianom fizycznym, chemicznym lub biologicznym. 
Prawo geologiczne i górnicze, w zakresie składowania odpadów w górotworze, zabrania rozcieńczania lub mieszania odpadów ze sobą lub innymi substancjami (przedmiotami) w celu spełnienia kryteriów dopuszczenia do składowania. Mając powyższe na uwadze odpady w podziemnych składowiskach składuje się w sposób selektywny. Składowanie odpadów w sposób nieselektywny jest dozwolone tylko wówczas, gdy nie wystąpi zagrożenie środowiska lub nie zostaną naruszone wymagania bezpieczeństwa (Ustawa z dnia 9 czerwca 2011 r.). Zasady umieszczania różnych rodzajów odpadów na poszczególnych typach podziemnych składowisk odpadów określone zostały z kolei w artykułach 106-108 Ustawy (Ustawa z dnia 14 grudnia 2012 r.).

Składowanie odpadów w sposób selektywny oraz opisane zakazy nie dotyczą jednak podziemnego składowania odpadów obojętnych oraz innych niż niebezpieczne i obojętne, jeżeli są to odpady wydobywcze w rozumieniu Ustawy (Ustawa z dnia 10 lipca 2008 r.).

\section{Podsumowanie}

Zgodnie z zapisami zawartymi w przeanalizowanych aktach prawnych, unijnych i krajowych, w pierwszej kolejności rekomendowane jest zapobieganie powstawaniu odpadów wydobywczych, ograniczanie ilości wytwarzanych odpadów wydobywczych, jak również minimalizowanie ich negatywnego oddziaływania na środowisko. Kolejnym krokiem w zagospodarowywaniu powstających odpadów wydobywczych jest ich odzysk, pod warunkiem, że jest on technologicznie i ekonomicznie uzasadniony oraz zgodny z przepisami o ochronie środowiska. Natomiast unieszkodliwianie odpadów, poprzez np. składowanie na składowiskach, jest ostatnim i ostatecznym etapem w całym procesie gospodarowania odpadami wydobywczymi.

W świetle obowiązujących regulacji prawnych do odpadów wiertnicznych można zastosować kilka z rekomendowanych w załączniku nr 2 do Ustawy o odpadach sposobów unieszkodliwiania odpadów, tj. procesy D1, D2, D3, D5, D7 oraz D9. Wśród możliwych sposobów unieszkodliwiania odpadów dopuszczone jest umieszczanie odpadów na składowiskach. Odpady powstające podczas działalności górnictwa naftowego i gazownictwa można zgodnie z obowiązującymi regulacjami prawnymi składować w:

- podziemnym składowisku odpadów lub

- obiekcie unieszkodliwiania odpadów wydobywczych.

W zależności od rodzaju składowanych w drugim przypadku odpadów, może to być obiekt unieszkodliwiania odpadów wydobywczych kategorii A (na którym, podobnie jak na składowisku odpadów niebezpiecznych, są deponowane odpady wydobywcze niebezpieczne) lub obiekt unieszkodliwiania odpadów wydobywczych inny niż kategorii A (na którym mogą być składowane odpady wydobywcze obojętne lub odpady wydobywcze inne niż niebezpieczne i obojętne, podobnie jak na składowisku odpadów obojętnych lub odpadów innych niż niebezpieczne i obojętne).

Mimo stosunkowo dużej ilości aktów prawnych dotyczących możliwego zagospodarowania/unieszkodliwiania odpadów pochodzących z działalności górnictwa nafty i gazu, na poziomie krajowym, brak jest nadal uregulowań wyczerpujących całą tematykę gospodarowania odpadami wydobywczymi. Polskie prawo jest często w przedmiotowym zakresie także niespójne. W ustawach znajdują się odwołania do rozporządzeń, które nie są już obowiązujące lub są uchylone bez zastąpienia. Znaleźć można również zapisy, które w związku z nowelizacją niektórych ustaw nie dotyczą już odpadów wydobywczych. Poza tym do określenia obiektów o tym samym przeznaczeniu używa się różnych definicji i pojęć. W Ustawie o odpadach wydobywczych obiekty, na których składuje się tego typu odpady to obiekty unieszkodliwiania odpadów wydobywczych, a w ustawie o odpadach to składowiska odpadów. Taka sytuacja i stosunkowo często zmieniane przepisy na pewno nie ułatwiają prawidłowego postępowania z odpadami wiertniczymi.

Artykuł powstał na podstawie pracy statutowej pt.: Analiza możliwości zagospodarowania odpadów pochodzacych z działalności górnictwa naftowego i gazownictwa - praca INiG - PIB na zlecenie MNiSW; nr zlecenia: 0077/GE/2019, nr archiwalny: DK-4100-0066/2019.

\section{Literatura}

Garbarino E., Orveillon G., Saveyn H.G.M., Barthe P., Eder P., 2018. Best Available Techniques (BAT) Reference Document for the Management of Waste from Extractive Industries. Publications Office of the European Union. DOI: 10.2760/35297.

Krasińska A., Król A., 2012. Ocena szkodliwości odpadów wydobywczych w świetle obowiązujących wymagań prawnych na przykładzie odpadów wytwarzanych podczas konwencjonalnego poszukiwania węglowodorów. Nafta-Gaz, 12: 1170-1175.

Kujawska J., 2020. Sposoby zagospodarowania i utylizacji zwiercin powstających przy poszukiwaniu gazu łupkowego. $<$ https:// docplayer.pl/5347646-Sposoby-zagospodarowania-i-utylizacjizwiercin-powstajacych-przy-poszukiwaniu-gazu-lupkowego. html> (dostęp: 19.03.2020).

Kukulska-Zając E., Dobrzańska M., 2012. Zarządzanie odpadami wydobywczymi w świetle najnowszych uregulowań prawnych. Nafta-Gaz, 12: 1183-1189.

Steliga T., Jakubowicz P., Kapusta P., Wojtowicz K., 2018 a. Efektywność biodegradacji zanieczyszczeń ropopochodnych w zestarzałym odpadzie z dołu urobkowego. Nafta-Gaz, 10 : 752-758. DOI: 10.18668/NG.2018.10.07.

Steliga T., Uliasz M., Jakubowicz P., Szajna A., 2018b. Zestalanie zużytych płuczek wiertniczych - próba półprzemysłowa. NaftaGaz, 11: 821-827. DOI: 10.18668/NG.2018.11.06. 


\section{Akty prawne i dokumenty normatywne}

Dyrektywa 2006/21/WE Parlamentu Europejskiego i Rady z dnia 15 marca 2006 r. w sprawie gospodarowania odpadami pochodzącymi z przemysłu wydobywczego oraz zmieniająca dyrektywę 2004/35/WE (Dz.U. L 102 z 11.4.2006 wraz z późn. zm.).

Dyrektywa Rady 1999/31/WE z dnia 26 kwietnia 1999 r. w sprawie składowania odpadów (Dz.U. L 182 z 16.7.1999 wraz z późn. zm.).

Rozporządzenie Ministra Gospodarki z dnia 16 lipca 2015 r. w sprawie dopuszczania odpadów do składowania na składowiskach (Dz.U. 2015 poz. 1277).

Ustawa z dnia 10 lipca 2008 r. o odpadach wydobywczych (Dz.U. 2008 nr 138, poz. 865 wraz z późn. zm.).

Ustawa z dnia 9 czerwca 2011 r. - Prawo geologiczne i górnicze (Dz.U. 2011 nr 163, poz. 981 wraz z późn. zm.).

Ustawa z dnia 14 grudnia 2012 r. o odpadach (Dz.U. 2013, poz. 21 wraz z późn. zm.).

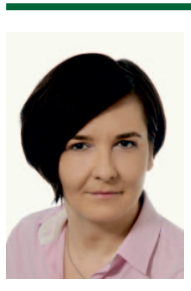

Dr Ewa KUKULSKA-ZAJĄC

Adiunkt; kierownik Zakładu Ochrony Środowiska

Instytut Nafty i Gazu - Państwowy Instytut Badawczy

ul. Lubicz 25 A

31-503 Kraków

E-mail: kukulska@inig.pl

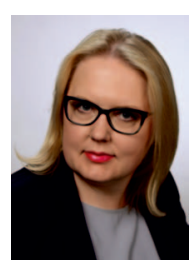

Dr Anna KRÓL

Adiunkt w Zakładzie Ochrony Środowiska

Instytut Nafty i Gazu - Państwowy Instytut Badawczy

ul. Lubicz 25 A

31-503 Kraków

E-mail: anna.krol@inig.pl

\section{OFERTA BADAWCZA ZAKŁADU OCHRONY ŚRODOWISKA}

analiza zagrożeń środowiska naturalnego, związanych z działalnością przemysłu naftowego i gazowniczego; opracowanie i weryfikacja technologii środowiskowych w przemyśle naftowym i gazowniczym;

monitoring i badania laboratoryjne jakości środowiska (powietrza, wód i gleby) na terenach poszukiwania i eksploatacij ztóż węglowodorów i innych terenach przemystowych;

- badania laboratoryjne ścieków i odpadów (w tym odpadów wiertniczych, odpadów po zabiegu hydraulicznego szczelinowania, odpadowych wód ztożowych i cieczy technologicznych) oraz ocena ich potencjalnej szkodliwości dla środowiska;

klasyfikacja odpadów wydobywczych wraz ze sporządzaniem podstawowej charakterystyki odpadu;

analiza zawartości rtęci w próbkach środowiskowych (statych i ciektych), mieszaninach gazowych i materiatach przemystowych;

- inwentaryzacja emisji metanu z sektora poszukiwania, wydobycia, magazynowania oraz przesytu i dystrybucij gazu;

ocena wielkości emisji gazów cieplarnianych;

ocena jakości paliw węglowodorowych: gazu ziemnego, koksowniczego, gazów wytwarzanych w przemyśle, biogazu;

kompleksowa analiza biogazu, w tym analiza związków krzemu, chloru i fluoru;

monitoring jakości gazu ziemnego w systemie gazowniczym;

sporządzanie oraz aktualizacja kart charakterystyki substancji i mieszanin niebezpiecznych, zgodnie z obowiązującym prawodawstwem;

pobieranie próbek wód, ścieków, gleb, odpadów oraz gazu ziemnego, biogazu i innego typu mieszanin gazowych.

Kierownik: dr Ewa Kukulska-Zając Adres: ul. Bagrowa 1, 30-733 Kraków Telefon: 1261774 36, 797727103 Faks: 126531665 E-mail: ewa.kukulska@inig.pl

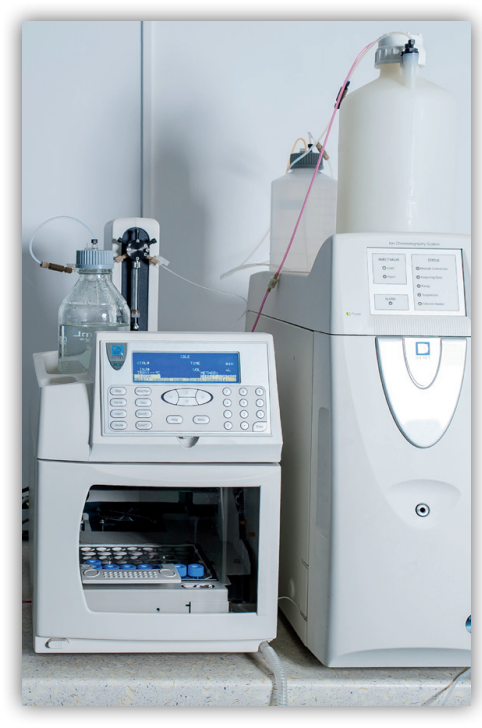

INSTYTUT NAFTY I GAZU

- Państwowy Instytut Badawczy 